\title{
Religion and the Modernity of Renaissance Humanism
}

\section{Citation}

Hankins, James. Religion and the modernity of Renaissance humanism. In Interpretations of Renaissance Humanism, ed. Angelo Mazzocco, 137-53. Leiden: E. J. Brill, 2006.

\section{Permanent link}

http://nrs.harvard.edu/urn-3:HUL.InstRepos:2920220

\section{Terms of Use}

This article was downloaded from Harvard University's DASH repository, and is made available under the terms and conditions applicable to Other Posted Material, as set forth at http:// nrs.harvard.edu/urn-3:HUL.InstRepos:dash.current.terms-of-use\#LAA

\section{Share Your Story}

The Harvard community has made this article openly available.

Please share how this access benefits you. Submit a story.

\section{Accessibility}




\title{
RELIGION AND THE MODERNITY OF RENAISSANCE HUMANISM
}

\author{
James Hankins
}

When some sixty years ago, in the middle of the Second World War, Paul Oskar Kristeller began his great project of reinterpreting Renaissance humanism, he could not possibly have imagined just how fruitful his hypothesis would prove to be in the decades to follow. As is well known, Kristeller rejected the historiographical tradition descending from Francesco Fiorentino, Bertrando Spaventa, Giovanni Gentile and Ernst Cassirer that tended to assimilate Renaissance humanism to modern philosophical humanisms - humanism as a philosophy of man-and insisted on historicizing the phenomenon. His goal was to make a clean distinction between contemporary humanism and the studia humanitatis of the Renaissance. ${ }^{1}$ For Kristeller humanism was a literary movement inspired by the antique but with its roots in the Middle Ages; in one famous formulation, he described the movement as a particular stage in the history of rhetoric; in another, as a cycle of disciplines embracing grammar, rhetoric, history, poetry and moral philosophy. ${ }^{2}$ Kristeller's interpretation of humanism, widely accepted in the Anglo-Saxon world, gave rise in its turn to a major historiographical tradition, and one which is still lively and creative, to judge from two recent books, Ronald Witt's 'In the Footsteps of the Ancients' and Robert Black's Humanism and Education in Medieval and Renaissance Italy. ${ }^{3}$

\footnotetext{
${ }^{1}$ See James Hankins, "Renaissance Humanism and Historiography Today," in Palgrave Advances in Renaissance Historiography, ed. Jonathan Woolfson (New York, 2005), pp. 73-96; also the article of Robert Black, "The Renaissance and Humanism: Definitions and Origins," in the same volume, pp. 97-117. See also my essays, "Two Twentieth-Century Interpreters of Renaisssance Humanism," and "Renaissance Philosophy between God and the Devil," both in Humanism and Platonism in the Italian Renaissance, 2 vols. (Rome, 2003-04), 1: 573-590 and 1: 591-615, respectively.

${ }^{2}$ Kristeller stated his views on Renaissance humanism in many places, but they are conveniently summarized in Paul Oskar Kristeller, "The Humanist Movement," in idem, Renaissance Thought and Its Sources, ed. Michael Mooney (New York, 1979), pp. 21-32.

${ }^{3}$ Ronald G. Witt, 'In the Footsteps of the Ancients': The Origins of Humanism from Lovato to Bruni (Leiden, 2000); Robert Black, Humanism and Education in Medieval and Renaissance Italy: Tradition and Innovation in Latin Schools from the Twelfth to the Fifteenth Century (Cambridge, Eng., 2001). For a recent Italian dissent from Kristeller's interpretation, see Riccardo Fubini, "Renaissance Humanism and its Development in Florentine Civic Culture," in Palgrave Advances, pp. 118-38.
} 
Witt and Black are hardly in accord on every issue, but it is worth pointing out that they are very much in agreement about one key element of Kristeller's view of humanism, namely, the continuity between medieval literary culture and Renaissance humanism. Both books, indeed, could almost be regarded as radicalizations or extreme forms of the Kristeller thesis. Witt's book makes the argument for continuity in far stronger terms than Kristeller ever did; for him, the origins of Italian humanism are to be found in the later thirteenth century, when certain figures in Tuscany and northeastern Italy took over the literary heritage of high medieval France, gradually extending and transforming it through various literary genres. Black's book insists on the continuity of grammatical instruction from the early thirteenth century through the end of the fifteenth, and argues that the real educational innovators in the Western humanist tradition are to be found, not in the early fifteenth, but in the twelfth and thirteenth centuries.

Belief in a fundamental continuity between medieval and Renaissance culture is undoubtedly now dominant through most of the Anglo-Saxon academic universe, and has had the predictable result of (further) undermining the period concept of the Renaissance. ${ }^{4}$ Even a scholar such as Quentin Skinner, who has recently reasserted the distinctiveness of Renaissance republicanism, has nevertheless himself done much to undercut that distinctiveness by his researches into medieval republican thought. ${ }^{5}$ The present writer has no wish to call the continuity thesis into question, and Kristeller, Witt and Black are doubtless correct in finding the roots of humanism as a stylistic ideal in the High Middle Ages (though one can also agree with Riccardo Fubini that the full ideological consciousness of the movement emerges only with Petrarch). ${ }^{6}$ Yet there is no contradiction in also examining the literary products of the humanists for the marks of modernity. Even if the posture of a man with one foot in the Middle Ages, saluting with the other the rising dawn of the Renaissance-to quote Charles Homer Haskins' famous dictum-is an awkward one, it is by no means an illogical one. Unless we believe, against all the evidence, that origins are destiny, or that the medieval and the modern are mutually exclusive categories, it seems

\footnotetext{
${ }^{4}$ See Fubini's acute remark in the article cited in the previous note (p. 123) that "It is evident that an historiography that approaches such an imposing break with tradition in a traditional spirit cannot but confound its own raison dêtre."

${ }^{5}$ Quentin Skinner, "Introduction: The Reality of the Renaissance," in Visions of Politics, 2 (Cambridge, 2002), pp. 1-9, but see chapters 2-4 in the same volume.

${ }^{6}$ Fubini, "Renaissance Humanism," pp. 123-24.
} 
perfectly possible a priori that at some point in its development, in some branches of its activity, the humanist movement developed ideas, methods and intellectual routines that are recognizably modern. It is even, dare one say it, perfectly possible that important aspects of modernity had their roots in the thought of the Italian humanists, even if the latter were primarily literary men and did not constitute a philosophical school.

One problem with hunting for the roots of modernity, of course, is that the idea of modernity is polysemous-its definition varies depending on whether one is an economic historian, an historian of the arts or of science, a social historian or an historian of politics and political theory. Modernity is also a moving target. What was modern for Burckhardt in the nineteenth century is no longer modern for us. For Burckhardt, what stood out as modern was the dominance of the nation state, liberal individualism, secularism and the decline of religious belief. None of these "modern" phenomena would necessarily be considered modern today. For example, many, especially in Europe, believe the nation state belongs in the dustbin of history and is destined to be replaced by supranational or international orders. While liberal individualism has enjoyed great success in the social sphere, morphing, since the 1960s especially, into the more radical and demotic forms of expressive individualism and the culture of authenticity, it has not been popular among political theorists for at least a generation, and its behaviors are more and more divorced from the political realm. Libertarians are just about the only theorists who still want to erect individualism into a political theory, and they are a tiny minority in the academy and the political sphere in general. And while institutional religion has continued to be moribund in Europe, the same is not true of the rest of the world. Christianity and Islam are the fastest-growing religions in the world, far outpacing the spread of secular philosophies, and it is the conservative, dogmatic forms of these religions which have proved the most successful, not their more liberal or "modern" variants. There may be a Unitarian or two in China, for all we know, but there are not many. Comte's positivist prophecy of a scientific and secular future has failed to materialize outside Western Europe, and even there is under threat from the spread of Islam. Hostility to dogmatism has a tendency to slide into lack of conviction, it seems, which is a poor defense against the passionate intensity of true believers. Even the Enlightenment hope for progress towards religious universalism, towards finding some "essence of religion" on which all religions could agree, thus bringing an end to religious war, has been fatally undermined. Modern anthropological and sociological understandings of religion as a family-resemblance concept 
makes it increasingly implausible that any reductionist approach to dogma will yield something like religious unity. ${ }^{7}$

It is religion that I wish to discuss here, and more particularly, the modernity of a certain strain of Renaissance humanism with respect to its understanding of religion. It can be argued, it seems to me, that philosophers like Nicolaus Cusanus, Marsilio Ficino, Pico della Mirandola, and Francesco Patrizi of Cherso explored a new way of thinking about religion that has numerous analogies with the way religion is understood in the contemporary world. It might be objected that, by Kristeller's definition of humanism, Cusanus, Ficino, Pico and Patrizi are philosophers, not humanists. But even if we embrace Kristeller's strict separation between humanists and philosophers, a conceptual operation not always easy to perform, it cannot be denied that these thinkers were deeply marked by humanist study of antiquity. The matter could be put even more strongly, for it is surely true that the humanist element in their thought that is primarily responsible for their attitude is religion. It was the effort to comprehend and incorporate ancient religious wisdom into Christianity that sparked Renaissance philosophy's most profound meditations on the nature of religion itself.

The understanding of religion I am referring to is found in texts such as Bessarion's Oratio dogmatica de Unione (1439), Cusanus' De pace fidei (1453), Ficino's De christiana religione (1474) and Theologia platonica de immortalitate (1482), Patrizi's Nova de universis philosophia (1593) and more implicitly in Pico's Oration and Nine Hundred Theses (1486). In these writings, Renaissance thinkers move beyond the antagonistic categories used to typologize religions that are found in ancient and medieval Christian writers: the categories of obsolescence and heresy. In these conceptions, as described by R.W. Southern and other scholars, Judaism and paganism are ordinarily relegated to the category of obsolescence. Though the Jews were vouchsafed a shadowy religious truth through the law and the prophets, that wisdom was now fulfilled and superseded by Christian revelation, and Jews who persisted in the old law were typically seen by Christians as "stubborn" or "stiff-necked" for their refusal to accept the new dispensation. The pagans had had their wise men, some of whom had intimations of Christian truth, but their religion was corrupt and pernicious, and their gods were demons bent on destroying true religion. Greek Orthodox Christians were heretics and schismatics, their defiance of Rome's authority

\footnotetext{
7 Anthony Giddens, Sociology (Oxford, 1989), p. 452; John Hick, The Interpretation of Religion: Human Responses to the Transcendent, 2nd ed. (New Haven, CT, 2004), pp. 3-5.
} 
leading them to embrace Trinitarian heresy about the procession of the Holy Spirit. Islam was the worst of all. Mohammed was a false prophet possessed by a demon, and the Koran was dictated by demons. The admixture of praiseworthy elements in it was merely a demonic ploy to delude the wise and good. Islam in general was an evil heresy, a scourge sent by God to punish faithless Christians. ${ }^{8}$

When the humanist movement began to gain ground in Italy in the later fourteenth century, these traditional, clerical attitudes and beliefs began to come under pressure. The popularity of the philosophical works of Cicero, with their urbane assumption that the theological beliefs of educated people had little or nothing in common with popular religion, surely had a wide impact. The De natura deorum in particular presented the innumerable humanist admirers of Cicero with an understanding of religion inimical to clerical dogmatism. Cicero goes so far as to claim (1.10) that dogmatic statements by authoritative teachers are a positive hindrance to honest inquiry. Cicero's own inclination to the reductive universalism of the Stoics (3.95), which amounts to a belief in God, Providence, the divine perfection of the world and human participation in divine reason, is combined with a prudential commitment to preserving traditional rites and ceremonies; he manages to convey the strong suggestion that in the expression of religious beliefs private convictions need to be subordinated to the public needs of the state $(2.168,3.5)$. The latter position is one echoed by Poggio in the Historia tripartita, Thomas More in his Utopia, as well as by Machiavelli and Montaigne, among others.

The humanist project in general, of course, entailed a more deferential attitude to pagan antiquity-indeed in some cases a positive adoration of the classical world-and this relative openness to pagan culture seems to have led to a kind of cognitive dissonance. Something had to be done to rescue pagan wisdom and distinguish it from the crude pagan superstitions excoriated by the Church Fathers. Thus Boccaccio and Salutati rediscovered the late third- and early fourth-century strand of Christian apologetics typified by Lactantius and Eusebius that found a close kinship between the theologies of the pagan philosophers and more sophisticated styles of Christian theology. This high paganism was ultimately, by Ficino and others, identified with Platonism and its forerunners, Hermetism, Orphism, and

\footnotetext{
${ }^{8}$ Norman Daniel, Islam and the West: The Making of an Image (Edinburgh, 1958); Richard W. Southern, Western Views of Islam in the Middle Ages (Cambridge, MA, 1962); Franco Cardini, Europe and Islam, trans. Caroline Beamish (Oxford, 1999); Nancy Bisaha, Creating East and West: Renaissance Humanists and the Ottoman Turks (Philadelphia, 2004).
} 
Zoroastrianism. To be sure, the more circumspect-and more authoritative-theologies of Jerome, Ambrose and Augustine a century later aimed to make clearer distinctions between what was pagan and what was Christian, even while exploiting the conceptual apparatus and authority of the pagan philosophers for apologetic ends. But Augustine, Ambrose and even Jerome could be read-and were read-selectively, as simple endorsements of the value of pagan philosophy to Christians.

My impression is that the effort to recover and incorporate this alien religious wisdom - the product of a separate revelation rather than mere natural reason-ultimately underlay the new attitude to religious diversity one finds in the fifteenth century, as well as the strikingly ecumenical attitudes of humanists at the Council of Florence. ${ }^{9}$ If the fourth-century Latin Church Fathers had been line-drawers, Quattrocento humanists were lineblurrers. They were eager to show the common ground between Christians and virtuous pagans-unlike Augustine or Jerome, who were concerned to make paganism less glamorous to Christians and potential converts. ${ }^{10}$ But the same receptive attitude could carry over to other religions, even contemporary religions. Thus Cusanus in the vision-dialogue De pace fidei (1453) employs a kind of metaphysical reductionism to translate Christian conceptions such as the Trinity, the Incarnation and the Redemption into terms acceptable to Muslims, Jews and Hindus. The Trinity, for example, is an expression of the inherent metaphysical interrelationship of unitas, aequalitas, and connexio. ${ }^{11}$ Cusanus hopes that his version of Neoplatonic metaphysics, particularly his Proclan principle of the coincidentia oppositorum, will provide a basis for inter-religious dialogue and religious peace. ${ }^{12}$ This is quite different from Thomas Aquinas' approach in the Summa contra Gentiles where certain general theological truths, "preambles of the faith," are established by natural reason as a preliminary to converting non-Christians to specifically Christian beliefs. Cusanus' position is

\footnotetext{
${ }^{9}$ On this see my Plato in the Italian Renaissance, 2 vols. (Leiden, 1990), 1: 221-225.

${ }^{10}$ See for example Augustine's remarkable De vera religione, where he tries to convince philosophical pagans that the spread of Christianity was the fulfillment of the wildest dreams of the philosophers for the spread of virtue and spiritual enlightenment.

${ }^{11}$ De pace fidei 6.17, in Nicolaus Cusanus, Opera omnia iussu et auctoritate Academiae Litterarum Heidelbergensis, 7.1-2: De pace fidei, cum epistula ad Ioannem de Segobia, ed. Raymond Klibansky and Hildebrand Bascour (Hamburg, 1959-70), p. 16. See Rudolf Haubst, Das Bild des einen und dreieinen Gottes in der Welt nach Nikolaus von Kues (Trier, 1952) for Cusanus' sources, particularly Augustine's De trinitate.

${ }^{12}$ See James E. Biechler, "Interreligious Dialogue," in Introducing Nicholas of Cusa. A Guide to a Renaissance Man, eds. Christopher M. Bellitto, Thomas M. Izbicki and Gerald Christianson (New York, 2004), pp. 270-296.
} 
that Muslims already believe distinctive Christian doctrines implicitly. In his later Cribatio Alkorani (1461) he tries to show that the teaching of Muhammed in the Koran is "implicitly trinitarian and christological,"13 and that a person "of vigorous intellect" who read the Koran piously would be led from the letter of the text and the sensible world to a knowledge of the divine. ${ }^{14}$ Here Cusanus' Neoplatonism appears to be the forerunner of Enlightenment universalism, anticipating the religious ideas of figures such as Ralph Cudworth and Matthew Tindal. Given this lineage it is perhaps no surprise that Cusanus' conception in the De pace fidei of "una religio in varietate rituum" bears a remarkable resemblance to the Oxford indologist F. Max Mueller's definition of religion as "a disposition which enables men to apprehend the infinite under different names and disguises." ${ }^{15}$

The same receptive attitude to non-Christian religious truths is found in Pico's Oration and Nine Hundred Theses. There, if my understanding of these texts is correct, pagan, Jewish, Islamic, Hindu and other theologies are mined with a view to enabling a higher synthesis, a synthesis still recognizably Christian, but immeasurably deepened, enriched, and strengthened by the treasuries of religious wisdom found in other traditions, including ancient theologies such as Platonism, Hermetism, Zoroastrianism, Orphism, medieval Arabic theology and Jewish Kabbalism. ${ }^{16}$ Pico's aim, to be sure, is not to show that all theologies agreed in all respects. He was not an eclectic of the ancient type who believed that all philosophers agreed in substance, disagreeing only about words. He held that every major theological tradition contained elements of truth and that these elements could be combined into a grand synthesis that was at the same time compatible with orthodox Christianity. Like Nicholas of Cusa in the Cribatio Alkorani, he believed that the understanding previous theologians had of the sources of their own theological traditions was not necessarily correct. In fact his aim was to construct a new theology using material from existing historical theologies as building blocks. His new theology would be superior to existing theologies because it would give a richer understanding of Christian

${ }_{13}$ Biechler, "Interreligious Dialogue," p. 285.

${ }^{14}$ See especially the Cribatio Alkorani, 1.20, "Digressio ad manuductionem divinorum," in Cusanus, Opera Omnia, vol. 8: Cribatio Alkorani, ed. Ludwig Hagemann (Hamburg, 1986), pp. 94-100.

${ }^{15}$ Cited by Alistair E. McGrath, Christian Theology: An Introduction, 3rd ed. (Oxford, 2001), p. 536.

${ }^{16}$ Giovanni Pico della Mirandola, Oration and Nine Hundred Theses, ed. Brian P. Copenhaver, forthcoming in the I Tatti Renaissance Library (Cambridge, MA, 2006). On Pico's concordism in general see Fernand Roulier, Jean Pic de Mirandole (1463-1494), humaniste, philosophe et théologien (Geneva, 1989). 
truths. This is not to imply that Pico was interested in directly challenging Christian dogmas. But he did wish (like many humanists) to move Christian theological speculation beyond the narrow circle of traditional authorities represented by Aristotle, the Bible and the Sentences of Peter Lombard. Situating Christian theology in the spectrum of world theologies would show both the superiority of Christian truth and the presence of Christian truths in all religions. Pico's ecumenism is therefore a militant ecumenism. In this respect, he reminds one of modern theologians like the Jesuit Karl Rahner. ${ }^{17}$ But it could be argued that Pico is even more open to nonChristian religious traditions than Rahner, given his hope that recovering the esoteric truths of other religious traditions would make the mysteries of Christianity more intelligible.

The first half of the sixteenth century was obviously not a period when ecumenical gestures towards non-Christian religions would find ready welcome, but before the passions of the Reformation took hold in the 1520s, it did produce one famous and influential text which mirrored the religious ideas of the Renaissance Neoplatonists, namely Thomas More's Utopia (1516). The relationship of this text to fifteenth-century Italian Platonism has not, I think, been fully appreciated. In the section of Utopia "On the Religions of the Utopians," More acknowledges that his Utopians have a number of religions, but the "vast majority, and those by far the wiser ones" hold to a philosophical conception of the divinity:

a single divinity, unknown, eternal, immeasurable, inexplicable, beyond the grasp of the human mind, and diffused throughout the universe, not by his mass, but by his power. Him they call their parent, and to him alone they attribute the origin, increase, progress, changes and ends of all things. ${ }^{18}$

Here More excludes a materialistic conception of the divinity, typical of ancient Stoicism, and like Plotinus, Proclus and Nicolaus Cusanus (but unlike Thomas Aquinas) sees God or the One as radically unknowable. As in ancient and Renaissance Platonic theology he is related to creation by his power (virtus), and is the source, pattern and goal of all created reality. More goes on to say that the Utopians call their god Mythra, who is

${ }^{17}$ Karl Rahner, S.J., "Christianity and the Non-Christian Religions," in Theological Investigations, 5 (London, 1966), pp. 115-34.

18 Thomas More, Utopia. Latin Text and English Translation, eds. George M. Logan, Robert M. Adams and Clarence H. Miller (Cambridge, Eng., 1995), p. 219 (the translation has been slightly adjusted). The Latin is: "unum quoddam numen putant, incognitum, aeternum, immensum, inexplicabile, quod supra mentis humanae captum sit, per mundum hunc universum virtute, non mole diffusum; hunc parentem vocant. Origines, auctus, progressus, vices, finesque rerum omnium huic acceptos uni referunt." 
generally identified by commentators with the Persian god Mithras. This suggests that More was thinking in terms of an ancient theology derived from Zoroastrianism, Mithras being often invoked in the Orphic Hymns which Ficino, following Pletho, attributed to Zoroaster. As Zoroastrianism was the form of religious wisdom specific to Asia in Ficino's conception, it was the most appropriate one for Utopia. The Utopians, More says, believe monotheism was established by the consensus of all nations (omnium consensu gentium) and states that Utopian society was moving away from a variety of superstitions in the direction of a single philosophical religion "more reasonable than any of the others" (quae reliquas ratione videtur antecellere). The fact the Utopians easily convert to Christianity, "either through the secret inspiration or because Christianity seemed very like the sect that most prevails among them," is meant to show, I think, that Utopia is simply at an earlier stage of historical development vis á vis religion, and that their ancient philosophical religion has well prepared them to receive the truths of the Gospel-so long as these are not presented in an exclusivist way. ${ }^{19}$ The state religion of Utopia enforces belief only in the doctrines of Providence and the immortality of the soul, the basis of all religion according to Ficino, and public worship is so organized as not to exclude any particular religion; rites peculiar to particular religions are practiced in private. Utopus is said to have been against dogmatism on the grounds that God perhaps likes "diverse and manifold forms of worship (cultus) and hence inspires different people with different ones," ${ }^{20}$ a view that echoes Ficino's statement in the De christiana religione that variety of worship “in accordance with God's ordination, perhaps engenders a certain marvelous glory in the world." ${ }^{21}$ Like Cusanus's vision of religious unity in the De pace fidei (una religio in varietate rituum), all Utopian religions agree on the central truth of religion, the worship of God: "they are like travelers going to a single destination by different roads." 22

More's proto-Enlightenment message of using philosophy to overcome religious discords was largely drowned out in the clamor of Reformation controversy. But when Ficinian Platonism was revived in the later sixteenth century it is clear that one of the attractions of his pia philosophia was

19 Ibid., pp. 218-223.

20 Ibid., pp. 222-3; see also note 22.

${ }^{21}$ Marsilio Ficino, Opera omnia, 2 vols. (Basel, 1576, repr. Turin, 1983), 1: 4.

22 More, Utopia, p. 235: "Quae quoniam non est ibi apud omnes eadem [religio], et universae tamen eius formae quamquam variae ac multiplices in divinae naturae cultum velut in unum finem diversa via commigrant, idcirco nihil in templis visitur auditurque quod non quadrare ad cunctas in commune videatur." 
the hope it offered of religious concord. The motive is stated explicitly in the preface to Francesco Patrizi da Cherso's Nova de universis philosophia, published in 1593 and dedicated to Pope Gregory XIII "and to all Future Roman Pontiffs." ${ }^{23}$ In the preface to this work, Patrizi denounces contemporary philosophy, citing the common saying: "He's a philosopher, he doesn't believe in God." "People see that in all the gymnasia of Europe, in all the monasteries, only Aristotelian philosophy is taught with great ambition and with great rewards." It was only Platonic philosophy, pious philosophy, which could heal the divisions of the Christian commonwealth, supply an adequate philosophical support for Christian theology, and provide the strongest weapons in the battle against heresy. For Patrizi, as for Cusanus, the best remedy for heresy was to absorb and sublimate its partial, merely verbal truths into a higher metaphysical truth. By reforming Catholic theology along Platonic lines Patrizi hoped to tap into an ancient wisdom that would permit a higher theological synthesis-a synthesis that could in turn embrace, rather than suppress, theological traditions outside of the Roman Church, including Judaism, Islam, paganism, and the religious beliefs of pre-Columbian civilizations in the New World. The old marriage between Christian theology and Aristotelianism, Patrizi believed, was now dysfunctional, and could lead only to the forcing of consciences and the use of violence against those outside the Church. Patrizi urges the Pope to have his new universal Platonic philosophy be taught everywhere in Christendom so that Christian wisdom may be renewed.

In short, the Renaissance Platonists can be seen as pioneers of modern interfaith dialogue, the dialogue that is so prominent a feature of organized religions today. It is true that none of them could be described as true religious pluralists, as they did not regard all religions as equally valid pathways to spiritual reality. ${ }^{24}$ That position seems to depend on an assumption of the indemonstrability of religious truth, which is in turn dependent on a more

${ }^{23}$ Francesco Patrizi da Cherso, Nova de universis philosophia libris quinquaginta comprehensa, in qua Aristotelica methodo non per motum sed per lucem \& lumina ad primam causam ascenditur, deinde nova quadam ac peculiari methodo tota in contemplationem venit divinitas, postremo methodo Platonica rerum universitas à conditore Deo deducitur, auctore Francisco Patritio, philosopho eminentissmo et in celeberrimo Romano gymnasio summa cum laude eandem Philosophiam publice interpretante (Venice, 1593). See James Hankins, "Plato's Psychogony in the Later Renaissance: Changing Attitudes to the Christianization of Pagan Philosophy," forthcoming in the proceedings of the conference Die Rezeption von Platons «Timaios» in Antike, Mittelalte und Renaissance, Villa Vigoni, Lake Como, 21-25 May 2003, to be published in Ancient and Medieval Philosophy, vol. 32, eds. Thomas Leinkauf and Carlos Steel (Leuven, 2005), pp. 393-412.

24 The terms "pluralist" and "inclusivist" (below) are taken from McGrath, Christian Theology, pp. 544-51. 
modern epistemology than was available in the Renaissance. ${ }^{25}$ But there is considerable common ground between Renaissance Platonists and modern inclusivist theologians, found primarily in the Catholic and Anglican churches, who emphasize the religious truths found in other traditions. Karl Rahner's argument that Christians should be able to discern valid elements in the holy books of other faiths, just as they find still valid truths in the Old Testament, has a precise parallel in Ficino's idea of an ancient theology whose wisdom is still of high value in the post-Incarnational world. Even if Renaissance Platonists might not have gone so far as Rahner in affirming the soteriological potential of other faiths-at least in the interest of avoiding unwanted attentions from the Inquisition-they perhaps go farther than Rahner in asserting the potential of other faiths to illuminate the Christian faith. Had there been fewer constraints on freedom of religious expression, it is possible, even likely, that the Platonists' tendency to conflate salvation and contemplative union with God would have led to a more robust affirmation of the possibility of salvation outside the Church. Ficino's famous comparisons of Socrates with Christ and Moses with Plato in Book 8 of his Letters suggest as much. ${ }^{26}$

Ficino is perhaps the Renaissance thinker who meditated most profoundly on the nature of religion, and his writings illustrate a number of ways in which the situation of Renaissance Christians anticipates the modern religious situation-or perhaps one should say the modern religious predicament. If we turn to Book 14 of the Platonic Theology, for example, we find in chapters 9 and 10 a remarkable discussion of religion which is here, of course, instrumental to the work's larger purpose of proving the immortality of the soul. ${ }^{27}$ Ficino begins by asking what constitutes the distinct perfection of human nature-what is it that truly separates mankind from the animals? It is not the ability to make different objects or to govern ourselves, since the beasts also do this in a way. It is not speech that distinguishes us, as Cicero or Valla might claim, since the animals

\footnotetext{
${ }^{25}$ See Hick, An Interpretation of Religion, whose pluralism is built on Kant's distinction between the noumenal (the transcendent) and the phenomenal (particular beliefs of world religions).

${ }_{26}$ Marsilio Ficino, Epistole (Venice, 1495), conveniently available in facsimile with a collation of the MSS. in The Letters of Marsilio Ficino, trans. Members of the Language Department of the School of Economic Science, London, 7 (London, 2003), pp. 157-86; the relevant letters are on pp. 159-62. For a perceptive discussion of natural religion in Ficino, see Paul Richard Blum, "La religione naturale di Marsilio Ficino," in Marsile Ficin ou les Mystères Platoniciens, ed. Stéphane Toussaint (Paris, 2002), pp. 313-26. On the possibility of the salvation of the pagans, see further below.

${ }_{27}$ Marsilio Ficino, Platonic Theology, eds. and trans. Michael J.B. Allen and James Hankins, 5 vols. to date (Cambridge, MA, 2001-2005), 4: 290-329.
} 
also communicate for social purposes. It is not even practical or speculative reason, for even these activities "seem to have a shadowy counterpart among the beasts." Here, of course, Ficino is breaking radically with the Aristotelian tradition, which regarded reason as the specific difference of human nature, and his discussion of the rational powers of beasts makes him sound almost like Darwin in The Descent of Man (chapters 3-4). What Ficino identifies as the special perfection of man is religion, defined as contemplation of the divine, or shortly afterwards as "that instinct which is common and natural to all peoples and which we everywhere and always use to think about Providence and to worship it as the queen of the world." Humanity is led to this universal piety by a "natural sagacity infused in us by Providence itself"; by philosophical reasons (especially the argument from design); and by prophecy and miracles. As we have already learned in Book 13, prophecy and miracles are phenomena by no means confined to the Christian world, but are found wherever the divine darts down and orders time and nature after its own image. ${ }^{28}$ And since mankind is naturally social, it naturally stands in need of a divine lawgiver, whether his name is Moses, Numa Pompilius, or Mohammed.

This is not to say that all revelations are equal, of course, and in the De christiana religione we learn that, if Christianity is not the only avenue of God's self-disclosure, it is the highest. "At no time does Divine Providence allow any part of the world to be without some kind of religious wisdom"Hermetism in Africa, Zoroastrianism in Asia, Orphism and Druidism in Europe-but there are higher and lower forms of religious wisdom, and there are also moments in history when religious wisdom has lain dormant or hidden in obscurity. ${ }^{29}$ Christianity is the highest and clearest and fullest form of religious wisdom, the wisdom that provides keys to unlock the mysteries of other religious traditions. Still, the divine is naturally knowable by all men, and for Ficino, as for Cusanus and More's Utopians, the rite according to which one worships is ultimately less important than what and how one worships. As he writes in the argument to Plato's Laws, Book 8,

${ }^{28}$ Note that, unlike Aquinas, Ficino does not distinguish between Christian miracles done in virtute divina and non-Christian miracles; like Avicenna Ficino has a naturalistic account of miracles that assimilates them all, pagan and Christian, to the same set of supranormal psychic powers. See James Hankins, "Ficino, Avicenna and the Occult Powers of the Soul," forthcoming in the proceedings of the conference La magia nell'Europa moderna. Tra antica sapienza e filosofia naturale: tradizioni e mutamenti (Florence, Istituto Nazionale di Studi sul Rinascimento). More's Utopia also seems to defend the idea of non-Christian miracles which the Utopians believe to be "direct and visible manifestations of the divinity." More, Utopia, pp. 226-7.

${ }_{29}$ Ficino, Opera omnia, 1: 31-32. 
Plato held one should not pay so much attention to the rite according to which one worshipped, as to the reason why one worshipped. For if you did this for the sake of the highest king of all [an epithet of God used in ps. Plato, Epistulae 2.312e] and out of desire for eternal goods, it is probable that from whatever source and in whatever way you begin, you will through worship of this kind at some time approach nearer the highest, and either be surrounded by his immense light or at least saved by his overflowing goodness. ${ }^{30}$

The last phrase is roughly equivalent to "perfected in intellect or at least in will"; the need for both faculties to be perfected is a common Augustinian theme in Ficino's philosophy.

Ficino seems here to be saying through Plato's mouth that divine illumination and salvation are available to all men, irrespective of the religious rites they follow-even perhaps that the Beatific Vision and summum gaudium are available to non-Christians. As generally in his writings, he assimilates the Platonic vision of the Good to the Beatific Vision.

It should be noted that Ficino's attitude to other religions in these passages is not one of mere tolerance. Tolerance implies that one is oneself in possession of the truth but for prudential reasons one does not wish to force consciences. Nor can we describe Ficino's attitude as relativistic. Ficino is not saying that all religions are equally true, equally valuable pathways to the divine; nor, certainly, is he following that other form of cultural relativism which says that the multiplicity of religions proves that they are all false. Nor again is his attitude ecumenical, in the sense of aiming at a single understanding of Christianity or at a single, unified world religion. His attitude is closer to what Charles Taylor has described as neo-Durkheimian, typified by American denominationalism. One believes one's own religion, one thinks it stands closest to the truth. It is a guide and an avenue to authentic religious experiences. But one also respects other religious traditions, and even approves of them in a civic context as positive influences on the behavior of one's fellow-citizens. One assumes that other religions enable valuable religious experiences, that they contain a form of religious wisdom; one may even come to the point of wanting to learn from other religions and to incorporate their insights into one's own. It is an attitude of respect for and openness to other religious traditions, even if the principle in Ficino's case (as in Cusanus') is sometimes vitiated by intolerant outbursts against particular aspects of non-Christian religions, especially Judaism. ${ }^{31}$

\footnotetext{
${ }^{30}$ Platonis opera, trans. Marsilio Ficino (Venice, 1491), f. 300ra.

${ }^{31}$ Charles Taylor, Varieties of Religion Today (Cambridge, MA, 2003), pp. 93-94.
} 
Chapter 10 of the Platonic Theology, Book 13, is even more radically modern in the view it reveals of the religious condition of mankind. In this chapter Ficino is taking on-if I am not mistaken for the first time in the history of Christian apologetics-the materialistic etiology of religion found in Lucretius' De rerum natura. Lucretius, though not denying the existence of the gods, understands religious fear of the gods to be an irrational emotion having its source in ignorance and the weakness of human nature, reinforced by corrupt custom. Organized religions, especially those sponsored by the state or invented by primitive lawgivers, exploit these fears in order to coerce good behavior from wayward citizens. But a just view of nature, man and society such as Epicurus offered allows the philosopher to lay aside religious fear, as well as the psychic disturbances and other evils it causes, and to achieve tranquility.

Ficino responded to this primitive psychology of religion with a kind of psychology of irreligion, or perhaps one should call it a physiology of irreligion. ${ }^{32}$ For Ficino it is axiomatic that religion is natural to mankind, and a pious disposition is the natural product of balanced sanguine humors, or in other words of health and sanity. One might observe in passing that this view is perhaps not as unscientific as it might sound, and a number of evolutionary psychologists and anthropologists regard religious belief as a biological universal..$^{33}$ In any case, for Ficino it is unbelief that requires explanation, not belief. Ficino sees the unbelief characteristic of artists and intellectuals as the result of an excess of ratiocination, resulting in the predominance of the melancholic humor-dry, cold and black. "Such a humor," writes Ficino, "being the contrary of life, banishes life's hope and injects doubt, the enemy of life, into the rational soul." Doubt is literally a disease of the soul, and it is this disease of depression or melancholy, sometimes exacerbated by astrological conditions, that is responsible for the irreligion of intellectuals. "They doubt, not because they excel in intellectual ability and doctrine, but because the earthy humor makes them doubtful and cowardly." ${ }^{34}$ The tendency of the melancholic humor to engender religious doubt in intellectuals was one reason, perhaps the chief reason, why Ficino

\footnotetext{
${ }^{32}$ Compare Augustine, De vera religione 38.69; In Joannis evangelium tractatus 106.4; Enarratio in Psalmos 53.2; De trinitate 8.3.4.

${ }^{33}$ Steven Pinker, The Blank Slate: The Modern Denial of Human Nature (New York, 2002), appendix, and Pascal Boyer, Religion Explained: The Evolutionary Origins of Religious Thought (New York, 2001), especially chapter 1.

${ }^{34}$ Ficino, Oper omnia.
} 
devoted so large a part of his treatise on magic, the De vita, to combating this dangerous disposition to impiety.

In the course of his attack on Lucretius there emerges implicitly from Ficino's pages another figure, a contemporary of his, the Renaissance doubter. He is a young man, confident in his own powers of reasoning, disinclined to accept authority, always demanding a reason for everything, morally and constitutionally incapable of seeing the hidden metaphysical principles upon which religion rests. He is likely to be idle, licentious, flippant and a lover of the ridiculous-perhaps a Luigi Pulci or a Piero di Cosimo; perhaps even a Lorenzo de' Medici. ${ }^{35}$ At a more advanced age he will be bitter, without hope, depressed and incurious. It is this sort of man that Ficino is urging not to give up on religion. Such a man should realize that the wisdom of religion is not going to be apparent to him until he has had more experience of life, until the riot of his passions has subsided with age, until he has trained himself morally and intellectually to receive higher truths that are not available to the lumen siccum of the pure rationalist. The contemplative life requires more than cleverness, more than the vigorous exercise of the brain; it is a spiritual discipline requiring faith, hope and charity. That spiritual discipline gives us a vision of the whole, a rich sense of the world's meaning from which an understanding of the divine can flow.

It is in this dialogue between the religious philosopher and the rationalist doubter that we can glimpse something of the modern condition in matters of religion. Mutatis mutandis, we might even see William James in his Varieties of Religious Experience (1903), a book now over a hundred years old, but still in print, a foundational text in the modern discipline of the psychology of religion, and a work described recently by Clifford Geertz as "still highly relevant to contemporary conditions." ${ }^{36}$ Here and in his essays on The Will to Believe (1897) James argued, in a way reminiscent of Ficino, against scientific rationalists ("humanists" as they would later be called in America) who regarded religion as simply irrational, sentimental balderdash, a thing of the past. James, by contrast, saw scientific rationalism as too thin, somehow, not capturing enough of the mystery of life, not addressing the deep questions. For those deeper questions, James thinks, we need religious answers, even if those answers cannot immediately withstand

\footnotetext{
35 James Hankins, "Lorenzo de' Medici as a Student of Ficino: The De summo bono," in Humanism and Platonism, 2: 317-350.

${ }^{36}$ Clifford Geertz, Available Light (Princeton, NJ, 2000), p. 185.
} 
the rationalist's cross-examination. But James, like Ficino, feels the need to defend this suspense of one's critical faculties; he needs in other words to elaborate an ethics of belief. So James mounts a powerful argument that religion is a domain where belief is necessarily antecedent to grasping the truths of faith.

There are cases where a fact cannot come at all unless a preliminary faith exists in its coming. And where faith in a fact can help create the fact, that would be an insane logic which should say that faith running ahead of scientific evidence is the "lowest kind of immorality" into which a thinking being can fall. Yet such is the logic by which our scientific absolutists pretend to regulate our lives! ${ }^{37}$

As interpreted by Charles Taylor, James is "building on the Augustinian insight that in certain domains love and self-opening enable us to understand what we would never grasp otherwise."38 Taylor quotes Augustine's dictum in the Contra faustum (32.18), (Non intratur in veritatem nisi per charitatem), assimilating it to James' justification of his ethics of belief: "Better risk chance of error than loss of truth." Taylor's Augustinian parallel might tempt us to dismiss Ficino's engagement with religious skepticism as an eternal problem, not a distinctively modern one. Every age has its believers and its skeptics, one might claim; Augustine, Ficino and James were all engaged in a common, transhistorical dialogue between those who demand reasons before believing and those who think one must believe in order to understand.

Charles Taylor is an authoritative historian of philosophy as well as an eminent philosopher, and one hesitates to disagree with him. Yet it seems to me a mistake, an anachronism, to neglect the key differences between the Augustinian and the Jamesian projects. As an attentive reading of the Confessions I think shows, Augustine's belief that love or charity is the portal of truth is not tantamount to a belief in the necessity of a leap of faith. To be sure, grace and love guide the intellect to truth and allow the intellect to abide in truth. Certainly love gives stability to the truths of reason. But grace and love have no direct cognitive or pre-cognitive function. In his own path to Christianity Augustine already knew the truth intellectually before he committed his will to God; charity impelled his will to embrace a truth already known. Above all, Augustine's account of conversion has no concern specifically with the ethics of belief. He does not think of Christian

37 William James, Pragmatism and Other Writings, ed. Giles Gunn (London, 2000), p. 214, emphasis in the original.

38 Taylor, Varieties of Religion Today, p. 47. 
faith as potentially compromising rationality; Christian teaching for him is a conclusion of reason.

In this respect, despite the innumerable other differences between Ficino and James, the Florentine philosopher is in James' world and not in Augustine's. It must of course be granted that what motivates Ficino's plea to suspend antecedent demands for proof in undertaking religious commitment is motivated by considerations quite different from the pragmatist motives invoked by James. Nevertheless, Ficino lives in the same atmosphere of religious doubt as James does. Ficino lived in a world of university intellectuals where the great majority of trained philosophers regarded Christian belief, for example the belief in the immortality of the soul, as incompatible with the most prestigious natural philosophy of the day, that of Aristotle as interpreted by Averroes and Alexander of Aphrodisias. ${ }^{39}$ What gives Ficino's dialogue with the Lucretiani, Epicurei and other skeptics its distinctively modern cast is precisely its focus on the psychology and ethics of belief-what causes someone to believe or disbelieve, and why one might ethically have an obligation to believe or not to believe. These were not themes that greatly exercised ancient or medieval thinkers, but they have become central problems for religious thinkers in a world where the scientific world-view and scientific method, on the one hand, and religious belief and religious modes of believing, on the other hand, appear to have parted ways. It is, I believe, a strong argument for the modernity of the Renaissance that such issues begin to be explored with ever greater intensity and sophistication by humanistic thinkers like Marsilio Ficino.

\footnotetext{
39 See the famous passage in the preface to his Plotinus translation (Opera omnia, 2: 537 ) where Ficino states, with some exaggeration, that totus ferme terrarum orbis has been taken over by two sects of Aristotelians, the Averroists and the Alexandrians. On Ficino's quarrel with secularizing university intellectuals see my "Marsilio Ficino as a Critic of Scholasticism," in Humanism and Platonism, 2: 459-70.
} 